7. Reprod. Fert. (1972) 30, 117-124

\title{
ORAL ANTIFERTILITY EFFECTS OF HALO PROPANEDIOL DERIVATIVES IN MALE RATS
}

\author{
U. K. BANIK, T. TANIKELLA* AND S. RAKHIT \\ Ayerst Research Laboratories, Montreal 381, Canada \\ (Received 8th Fune 1971, accepted 15th October 1971)
}

\begin{abstract}
Summary. Ten derivatives of halo propanediol were tested orally for male antifertility effects in adult Sprague-Dawley rats. Six of these compounds were effective in inducing temporary sterility at a daily dose ranging from 2.5 to $5 \mathrm{mg} / \mathrm{rat}$. When administered over a minimum period of 7 days, these minimum effective doses did not interfere with the mating behaviour and spermatogenesis even during prolonged medication. However, at ten times the minimum effective dose, Compounds III (1-chloro-2,3-propanediol) and VII (1-chloro-2,3-bis[tetrahydropyran-2-yloxy]propane) caused severe testicular damage and irreversible sterility, while Compound X (4-[chloromethyl]-2-pentyl-1,3-dioxolane) did not. Our studies confirm that the presence of an $\alpha$-chlorohydrin group is essential in halo propanediol derivatives for antifertility effects in male rats.
\end{abstract}

\section{INTRODUGTION}

The need for a selective chemosterilant for controlling wild rat populations has now been well recognized (Marsh \& Howard, 1969). Within the last few years, a number of papers were published on the post-testicular antifertility effect of I-chloro-2,3-propanediol ( $\alpha$-chlorohydrin) and some related compounds in male rats (Coppola, 1969; Gunn, Gould \& Anderson, 1969; Jones, Davies, Edwards \& Jackson, 1969; Ericsson, 1970; Samojlik \& Chang, 1970; Setty \& Kar, 1970; Turner, 1971). It has also been reported that $\alpha$-chlorohydrin will inhibit fertility in male guinea-pigs (Ericsson, 1970) and monkeys (Setty, Kar, Roy \& Chowdhury, 1970; Kirton, Ericsson, Ray \& Forbes, 1970). The precise mode of action of this compound is still obscure. Most of the investigators, however, do agree that this compound produces an antifertility effect in males without interfering with spermatogenesis or disturbing mating behaviour.

In our laboratories, a series of known and novel compounds have been prepared, some of which are related to $\alpha$-chlorohydrin and we have studied their antifertility effects in Sprague-Dawley male rats. The purpose of this report is to summarize the results of our findings with these compounds.

The chemical formulae and structures of these compounds with their respective effective and ineffective doses as Imale chemosterilants are presented in Text-fig. 1.

* Present address : Department of Pharmacology, Dalhousie University, Halifax, Canada. 


\section{MATERIALS AND METHODS}

Experiments were conducted on adult (300 to $450 \mathrm{~g}$ ) Sprague-Dawley male rats received from the Charles River Laboratories, Mass., U.S.A. At least five animals were used in each group. All compounds were dissolved in dimethylsulphoxide and administered orally in a dose of $0.2 \mathrm{ml} / \mathrm{rat} /$ day. The control animals received the vehicle only. The fertility of each control and treated

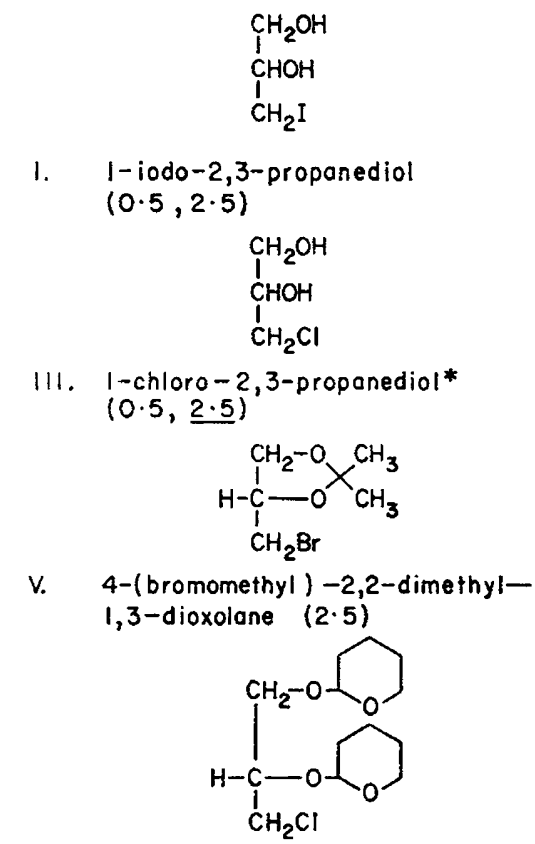

VII. i-chloro-2,3-bis (tetrahydropyran-2-yloxy) propone $(2 \cdot 5, \underline{5 \cdot 0)}$<smiles>CC(C)OC(C)CCl</smiles>

1X. 2-(chloromethyl)-1,4-dioxospiro $[4,5]$ decane $(2.5)$

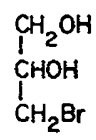

11. 1-bromo-2,3-propanediol (2.5)<smiles>CC1COC(C)(C)OC1</smiles>

IV. 4-(chloromethyl) -2,2-methyl-1,3dioxolone $(0.5, \underline{2.5})$<smiles>CC(=O)OCC(CCl)OC(C)=O</smiles>

VI. 1-chloro-2,3-propanediol diacefate $(0.5, \underline{2.5})$<smiles>CC(CCl)OC(C)OCc1ccccc1</smiles>

VIII, 4-chloromethyl-2-phenyl-1,3dioxolone $(0.5,2.5)$<smiles>CCCC(C)(C)OCC(C)CCl</smiles>

X. 4-(chloromethyl)-2-methyl-2pentyl-1,3-dioxolane $(0.5, \underline{2.5})$

Text-Fig. 1. The chemical structures and formulae of the compounds tested. The doses administered in $\mathrm{mg} / \mathrm{rat} / \mathrm{day}$ are given in parentheses, with doses effective in inducing sterility underlined. * Compound III is commonly known as $\alpha$-chlorohydrin.

male was tested before treatment. Unless otherwise stated, each male was again tested several times, starting on the 8th day of treatment, to check mating behaviour and fertility by allowing cohabitation $\left(1 \sigma^{*}: 1\right.$ \%) with sexually receptive pro-oestrous females of the same strain. Day 1 of pregnancy was dated from the day of finding a vaginal plug or spermatozoa in the cohabiting females. At least 2 days' rest was permitted for males between two cohabitations. The presence of fertilized eggs or implants in the female reproductive tract on Day 5 or 9 of pregnancy, respectively, was taken as evidence of fertility in male rats. The minimum effective dose (MED) of each compound was established as the 
daily dose in $\mathrm{mg} / \mathrm{rat}$ that induced sterility in at least $85 \%$ of the animals treated over a minimum period of 7 days. Fourfold contingency test tables (Mainland \& Murray, 1952) were used for statistical analysis of the number of matings and the number of rats which became pregnant.

In addition to the male antifertility test, a few other tests were also performed with some of the effective compounds.

\section{RESULTS}

Antifertility test of different compounds in male rats

Different doses of the test compounds were administered daily over a period ranging from 13 to 50 days and the results obtained in the test are presented in

TABLE 1

ANTIFERTILITY TEST OF DIFFERENT COMPOUNDS IN MALE RATS

\begin{tabular}{|c|c|c|c|c|}
\hline Compound & $\begin{array}{c}\text { Dose } \\
\mathrm{mg} / \mathrm{rat} / \mathrm{day} \\
\times \mathrm{No} \text { of days }\end{array}$ & $\begin{array}{l}\text { No. of male } \\
\text { rats treated } \ddagger\end{array}$ & $\begin{array}{c}\text { No. of male rats } \\
\text { becoming in- } \\
\text { fertile during } \\
\text { treatment }\end{array}$ & Remarks \\
\hline $\begin{array}{l}\text { DMSO } \\
\text { (control) }\end{array}$ & $\begin{array}{l}0.2 \mathrm{ml} \times \\
23 \text { and } 47 *\end{array}$ & 15 & $0 / 15$ & Inactive \\
\hline I & $\begin{array}{l}0.5 \times 50 \\
2 \cdot 5 \times 25\end{array}$ & $\begin{array}{l}5 \\
5\end{array}$ & $\begin{array}{l}0 / 5 \\
0 / 5\end{array}$ & $\begin{array}{l}\text { Inactive } \\
\text { Inactive }\end{array}$ \\
\hline II & $2.5 \times 30$ & 5 & $0 / 5$ & Inactive \\
\hline III & $\begin{array}{l}0.5 \times 50 \\
2.5 \times 17 \\
\text { and } 34 \dagger \\
25.0 \times 20\end{array}$ & $\begin{array}{r}5 \\
13 \\
10\end{array}$ & $\begin{array}{c}1 / 5 \\
13 / 13 \ddagger \\
10 / 10 \ddagger\end{array}$ & $\begin{array}{l}\text { Inactive } \\
\text { Active } \\
\text { Active }\end{array}$ \\
\hline IV & $\begin{array}{l}0.5 \times 22 \\
2.5 \times 13\end{array}$ & $\begin{array}{l}5 \\
5\end{array}$ & $\begin{array}{l}0 / 5 \\
5 / 5 \ddagger\end{array}$ & $\begin{array}{l}\text { Inactive } \\
\text { Active }\end{array}$ \\
\hline V & $2.5 \times 30$ & 5 & $0 / 5$ & Inactive \\
\hline VI & $\begin{array}{l}0.5 \times 19 \\
2.5 \times 31\end{array}$ & $\begin{array}{l}5 \\
5\end{array}$ & $\begin{array}{l}0 / 5 \\
5 / 5 \ddagger\end{array}$ & $\begin{array}{l}\text { Inactive } \\
\text { Active }\end{array}$ \\
\hline VII & $\begin{array}{r}2.5 \times 46 \\
5.0 \times 15 \\
25.0 \times 23 \\
50.0 \times 22\end{array}$ & $\begin{array}{r}5 \\
5 \\
10 \\
10\end{array}$ & $\begin{array}{c}0 / 5 \\
5 / 5 \ddagger \\
10 / 10 \dagger \\
10 / 10 \dagger\end{array}$ & $\begin{array}{l}\text { Inactive } \\
\text { Active } \\
\text { Active } \\
\text { Active }\end{array}$ \\
\hline VIII & $\begin{array}{l}0.5 \times 21 \\
2.5 \times 30\end{array}$ & $\begin{array}{l}5 \\
5\end{array}$ & $\begin{array}{l}0 / 5 \\
5 / 5 \ddagger\end{array}$ & $\begin{array}{l}\text { Inactive } \\
\text { Active }\end{array}$ \\
\hline IX & $2.5 \times 20$ & 10 & $0 / 10$ & Inactive \\
\hline $\mathrm{x}$ & $\begin{array}{r}0.5 \times 29 \\
2.5 \times 20 \\
25.0 \times 20\end{array}$ & $\begin{array}{r}5 \\
9 \\
10\end{array}$ & $\begin{array}{c}0 / 5 \\
8 / 9 \ddagger \\
10 / 10 \ddagger\end{array}$ & $\begin{array}{l}\text { Inactive } \\
\text { Active } \\
\text { Active }\end{array}$ \\
\hline
\end{tabular}

DMSO $=$ dimethylsulphoxide.

* Ten animals were treated for 23 days and five for 47 days.

+ Five animals were treated for 17 days and eight for 34 days.

¥ Significantly different $(P<0.01)$ from the control group.

Table 1. It was found that Compounds III, IV, VI, VIII and X were active in exerting an antifertility effect in male rats at a daily dose of $2.5 \mathrm{mg} / \mathrm{rat}$. Compound VII was effective at a daily dose of $5 \mathrm{mg} / \mathrm{rat}$ in this test. The other compounds listed were inactive at the indicated doses. 
Induction of temporary sterility

The MED of each compound (III, IV, VI, VII, VIII and X) was administered daily as before and the medication was continued over a period ranging from 13 to 34 days (Table 2). The MED of these compounds was $2.5 \mathrm{mg}$ except Compound VII whose MED was established previously as $5.0 \mathrm{mg}$ (Text-fig. 1). Except for one rat treated with Compound X, all males treated by these compounds remained sterile during the treatment period and on withdrawal of the compound, thirty-eight of thirty-nine animals recovered fertility. Only one rat in the Compound III-treated group did not recover fertility.

TABLE 2

INDUCTION OF TEMPORARY STERILITY IN MALE RATS

\begin{tabular}{l|c|c|c|c|c}
\hline Compound & $\begin{array}{c}\text { Dose } \\
\text { mg/rat/day } \\
\times \text { No. of days }\end{array}$ & $\begin{array}{c}\text { No. of } \\
\text { rats } \\
\text { treated }\end{array}$ & $\begin{array}{c}\text { No. of } \\
\text { rats becoming } \\
\text { sterile }\end{array}$ & $\begin{array}{c}\text { No. of rats } \\
\text { recovering } \\
\text { fertility on } \\
\text { withdrawal of } \\
\text { compound }\end{array}$ & Remarks \\
\hline $\begin{array}{l}\text { DMSO* } \\
\text { (control) }\end{array}$ & $0.2 \mathrm{ml} \times$ & 15 & $0 / 15$ & - & Inactive \\
III & 23 and $47 *$ & 13 & $13 / 13$ & $12 / 13 \ddagger$ & Reversible \\
IV & $2.5 \times 34$ & 13 & $5 / 5$ & $5 / 5$ & Reversible \\
VI & $2.5 \times 13$ & 5 & $5 / 5$ & $4 / 4$ & Reversible \\
VII & $2.5 \times 30$ & 5 & $5 / 5$ & $5 / 5$ & Reversible \\
VIII & $5.0 \times 15$ & 5 & $5 / 5$ & Reversible \\
X & $2.5 \times 30$ & 5 & $5 / 5$ & $4 / 4$ & Reversible \\
\hline
\end{tabular}

* See Table 1.

+ Fertility was restored in these animals within 2 weeks (range 2 to 14 days).

$\ddagger$ Number of animals tested for reversal effect.

\section{Effect of compounds on frequency of mating performance}

The results of the mating performance of rats treated with Compounds III, IV, VI, VII, VIII and X are presented in Table 3. The MED and a lower inactive dose of each compound were administered daily over a period ranging from 13 to 50 days. At the respective lower dosages, none of these compounds was significantly effective in suppressing mating performance and fertility during treatment. At the higher dose levels, there was no significant reduction of mating behaviour but fertility was significantly reduced as shown by the small number of pregnancies induced by these males.

\section{Attempted induction of permanent sterility}

Three test compounds (III, VII and X) were administered to groups of ten rats. Each animal received a daily dose of ten times the MED over a period of 20 to 22 days (Table 4). The fertility of these animals was tested before and during treatment and attempts were made to check the fertility of surviving rats. Compound III was found to be toxic, seven animals dying during the latter part of the treatment. While all the ten rats in this group mated with receptive females from the 8 th day of treatment, they were found to be sterile as 
no motile spermatozoa were present in the reproductive tract of the female rats. The three surviving males did not recover fertility even 84 days after the end of treatment. Compound VII induced sterility in all rats but one died on the 18th

TABLE 3

EFFEGT OF COMPOUNDS ON FREQUENCY OF MATING PERFORMANCE BY MALE RATS

\begin{tabular}{|c|c|c|c|c|c|c|c|}
\hline \multirow{2}{*}{ Compound } & \multirow{2}{*}{$\begin{array}{c}\text { Dose } \\
\text { mg/rat/day } \\
\times \text { No. of days }\end{array}$} & \multirow{2}{*}{$\begin{array}{c}\text { No. of } \\
\text { rats } \\
\text { treated }\end{array}$} & \multirow{2}{*}{$\begin{array}{c}\text { No. of } \\
\text { pairings } \\
\text { with } \\
\text { pro-oestrous } \\
\text { females }\end{array}$} & \multirow{2}{*}{$\begin{array}{l}\text { No. of } \\
\text { matings }\end{array}$} & \multirow{2}{*}{$\begin{array}{c}\text { No. of } \\
\text { rats } \\
\text { pregnant }\end{array}$} & \multicolumn{2}{|c|}{ Remarks } \\
\hline & & & & & & $\begin{array}{c}\text { Mating } \\
\text { performance } \dagger\end{array}$ & Fertility \\
\hline $\begin{array}{l}\mathrm{DMSO}^{*} \\
\text { (control) }\end{array}$ & $\begin{array}{l}0.2 \mathrm{ml} \times \\
23 \text { and } 47^{*}\end{array}$ & 15 & 69 & 54 & 53 & Good & Good \\
\hline III & $\begin{array}{l}0.5 \times 50 \\
2.5 \times 34\end{array}$ & $\begin{array}{r}5 \\
13\end{array}$ & $\begin{array}{l}37 \\
95\end{array}$ & $\begin{array}{l}20 \\
77\end{array}$ & $\begin{array}{c}13 \\
25\end{array}$ & $\begin{array}{l}\text { Good } \\
\text { Good }\end{array}$ & $\begin{array}{l}\text { Good } \\
\text { Very poor }\end{array}$ \\
\hline IV & $\begin{array}{l}0.5 \times 22 \\
2.5 \times 13\end{array}$ & $\begin{array}{l}5 \\
5\end{array}$ & $\begin{array}{l}32 \\
24\end{array}$ & $\begin{array}{l}25 \\
21\end{array}$ & 25 & $\begin{array}{l}\text { Good } \\
\text { Good }\end{array}$ & $\begin{array}{l}\text { Good } \\
\text { Very poor }\end{array}$ \\
\hline VI & $\begin{array}{l}0.5 \times 19 \\
2.5 \times 31\end{array}$ & $\begin{array}{l}5 \\
5\end{array}$ & $\begin{array}{l}16 \\
22\end{array}$ & $\begin{array}{l}12 \\
21\end{array}$ & $\frac{12}{0 \$}$ & $\begin{array}{l}\text { Good } \\
\text { Good }\end{array}$ & $\begin{array}{l}\text { Good } \\
\text { Infertile }\end{array}$ \\
\hline VII & $\begin{array}{l}2.5 \times 46 \\
5.0 \times 15\end{array}$ & $\begin{array}{l}5 \\
5\end{array}$ & $\begin{array}{l}29 \\
26\end{array}$ & $\begin{array}{l}25 \\
21\end{array}$ & 15 & $\begin{array}{l}\text { Good } \\
\text { Good }\end{array}$ & $\begin{array}{l}\text { Good } \\
\text { Infertile }\end{array}$ \\
\hline VIII & $\begin{array}{l}0.5 \times 21 \\
2.5 \times 30\end{array}$ & $\begin{array}{l}5 \\
5\end{array}$ & $\begin{array}{l}21 \\
26\end{array}$ & $\begin{array}{l}13 \\
23\end{array}$ & 13 & $\begin{array}{l}\text { Good } \\
\text { Good }\end{array}$ & $\begin{array}{l}\text { Good } \\
\text { Infertile }\end{array}$ \\
\hline $\mathrm{X}$ & $\begin{array}{l}0.5 \times 29 \\
2.5 \times 20\end{array}$ & $\begin{array}{r}5 \\
10\end{array}$ & $\begin{array}{l}19 \\
43\end{array}$ & $\begin{array}{l}19 \\
36\end{array}$ & $\begin{array}{c}11 \\
5 \$\end{array}$ & $\begin{array}{l}\text { Good } \\
\text { Good }\end{array}$ & $\begin{array}{l}\text { Good } \\
\text { Very poor }\end{array}$ \\
\hline
\end{tabular}

* See Table 1.

† Evaluated from the total number of matings following overnight cohabitation with pro-oestrous females.

$\ddagger$ Evaluated from the number of rats which became pregnant following mating.

S Significantly different $(P<0.01)$ from the control group.

TABLE 4

ATTEMPTED INDUGTION OF PERMANENT STERILITY IN MALE RATS

\begin{tabular}{l|c|c|c|c|c}
\hline Compound & $\begin{array}{c}\text { Dose } \\
\text { mg/rat/day } \\
\times \text { No. of days }\end{array}$ & $\begin{array}{c}\text { No. of } \\
\text { rats } \\
\text { treated }\end{array}$ & $\begin{array}{c}\text { No. of } \\
\text { rats } \\
\text { becoming } \\
\text { sterile }\end{array}$ & $\begin{array}{c}\text { No. of rats } \\
\text { recovering } \\
\text { fertility on } \\
\text { withdrawal of } \\
\text { compound }\end{array}$ & Remarks \\
\hline $\begin{array}{l}\text { DMSO* } \\
\text { (control) }\end{array}$ & $\begin{array}{l}0.2 \mathrm{ml} \times 23 \\
\text { and } 47^{*}\end{array}$ & 15 & $0 / 15$ & - & - \\
VII & $25 \times 20$ & 10 & $10 / 10 \dagger$ & $0 / 3 \S$ & Irreversible \\
X & $50 \times 22$ & 10 & $10 / 10 *$ & $0 / 4$ & Irreversible \\
& $25 \times 20$ & 10 & $10 / 10$ & $4 / 5$ & Reversible \\
\hline
\end{tabular}

* See Table 1.

† Seven out of ten rats in this group died during the latter part (17 to 20 days) of treatment.

$\ddagger$ Number of animals tested for reversal effect.

One died during treatment.

day of treatment. On withdrawal of the compound, four of the rats were tested periodically and found to be still sterile at 75 days.

In the Compound $\mathrm{X}$-treated group, all rats became infertile from the 8th 
day but remained sterile only temporarily after withdrawal of the compound. One of the five rats tested remained sterile for 3 months and the remaining rats recovered fertility within 13 days. All fifteen control animals were fertile.

\section{Effect of compounds on sperm transport and fertilization of eggs}

Higher doses of Compounds III ( $2.5 \mathrm{mg} / \mathrm{rat})$, VII ( $5 \mathrm{mg} / \mathrm{rat})$ and X $(2.5$ $\mathrm{mg} / \mathrm{rat}$ ) were administered daily as indicated in Table 3 . At least 7 days after treatment, each male was housed overnight with a pro-oestrous female. The mated females were then killed at 14.00 hours on the following day and vaginal smears and uterine and Fallopian tube-flushings were quickly checked microscopically for the presence of motile or immotile spermatozoa. No motile spermatozoa were found in the vagina, uterus and Fallopian tubes in any one of these groups of rats. However, immotile spermatozoa were found in the vagina and uterine horns of all groups of rats. In rats mated by control males, motile spermatozoa were found in both the uterus and the Fallopian tubes. By 14.00 hours, the corona radiata cells were dispersed from the eggs of all these rats and motile spermatozoa were still found in the Fallopian tubes. In the females mated with treated males, however, the eggs were still in the swollen portion of the ampulla with intact corona radiata cells.

\section{Effects on body and organ weights}

Compounds III, VII and X were administered daily to groups of ten male rats at daily doses of 25,50 and $25 \mathrm{mg} / \mathrm{rat}$, respectively, for a period of approximately 3 weeks. At the end of the treatment, five of the ten rats in each group were killed with chloroform and the weights of testes, seminal vesicles, ventral prostates, levator ani, pituitary and body were recorded. Tissues of the remaining five animals were prepared for histopathological examination. Animals treated with Compounds III and VII had atrophic testicles and epididymal lesions. There was a loss of body weight, as well as seminal vesicle and levator ani weights in rats treated with Compound III, and the weights of the ventral prostate and pituitary glands were slightly increased compared to those of the control. Only in Compound VII-treated rats was there a slight decrease in the weight of pituitary glands. Rats treated with Compound $\mathrm{X}$ had increased seminal vesicle and ventral prostate gland weights compared to those of the control.

\section{Histopathological examination of male reproductive organs}

Rats treated with Compounds III and VII had severe changes in their testicles. There were signs of complete absence of spermatogenesis as the tubules contained only spermatogonia and Sertoli cells. In Compound III-treated rats, there were more spermatogenic giant cells than in Compound VII-treated rats, but a reduction in the number of Leydig cells compared to the number present in the testes of rats in the other groups. The epididymal canals of rats treated with Compounds III and VII were devoid of spermatozoa and only a mixed type of cellular débris was visible in the lumen. No oedema was seen in the interstitial tissue. Since the tubules of the testicles and the canals of the epididymides were devoid of spermatozoa, they appeared separated from each other. 
The prostates and seminal vesicles of these rats did not show any pathological change. There were no apparent histological changes in the testes, epididymides, ventral prostates or seminal vesicles of rats treated with Compound X.

\section{DISCUSSION}

Our studies indicate that compounds VII and $\mathrm{X}$ were active in inducing sterility in adult male rats. These results are comparable to the results for $\alpha$-chlorohydrin (III) reported by earlier investigators (Coppola, 1969; Ericsson \& Baker, 1970; Ericsson, 1970; Gunn et al., 1969; Samojlik \& Chang, 1970; Setty \& Kar, 1970). At ten times the MED, Compounds III and VII caused irreversible sterility while Compound X did not. At the MED levels, these compounds had their antifertility effect at the post-testicular region, perhaps mediated in some way in the epididymis. The post-testicular antifertility effect of Compound III was also reported by the above investigators. However, the exact biochemical mechanism of effect(s) remains obscure. Since higher dose levels of Compounds III and VII caused severe damage to the testes and the animals did not recover fertility, these compounds could be classified as irreversible antifertility agents. On the other hand, since Compound $\mathrm{X}$ did not interfere with mating performance, and fertility in treated rats returned on withdrawal of the compound, it could be classified as a reversible chemosterilant for male rats.

Ericsson \& Youngdale (1970) demonstrated that the presence of an $\alpha$ chlorohydrin group, rather than a bromohydrin, is essential for the antifertility effect in male rats. Our studies on three 1-halo-2,3-propanediols (I, II and III) point to a similar conclusion, since only the chlorohydrin (III) had activity at $2.5 \mathrm{mg}$ while the iodo- (I) and bromo- (II) compounds were devoid of activity at $2.5 \mathrm{mg}$. Unlike the compounds tested by Ericsson \& Youngdale (1970), the compounds used in this study had the vicinal hydroxy groups protected in the form of various 1,3-dioxolane derivatives (V, VIII, IX and X), bistetrahydropyranyl ether (VII) or bis-acetate (VI). All these compounds, however, may, in vivo, give rise to the parent 1-chloro-2,3-propanediol. The inactivity of 2-(chloromethyl)-1,4-dioxospiro[4,5]decane (IX) at $2.5 \mathrm{mg}$ may be due to the lack of absorption through the gastrointestinal wall and/or difficulty in hydrolysis to the parent compound. From this limited study, 4-(chloromethyl)-2-methyl-2-pentyl-1,3-dioxolane (X) seems to be more active on a molar basis than 1-chloro-2,3-propanediol. This may be due to the preferential accumulation of Compound $\mathrm{X}$, which has a long lipophilic alkyl chain in the target organ. Only further studies with a radioactive compound would reveal whether it accumulates in the testes and other target organs in males.

\section{ACKNOWLEDGMENT}

Our sincere thanks are due to Dr E. Greselin who made histological sections of different tissues and evaluated them microscopically.

\section{REFERENCES}

Coppola, J. A. (1969) An extragonadal male antifertility agent. Life Sci. 8, 43.

Ericsson, R. J. (1970) Male antifertility compounds: U-5,897 as a rat chemosterilant. J. Reprod. Fert. $22,213$. 
ERicsson, R. J. \& BAKER, V. F. (1970) Male antifertility compounds: biological properties of U-5,897 and U-15,646. 7. Reprod. Fert. $21,267$.

Ericsson, R. J. \& Youngdale, G. A. (1970) Male antifertility compounds: structure and activity relationships of U-5,897 and U-15,646 and related substances. F. Reprod. Fert. 21, 263.

Gunn, S. A., Gould, T. G. \& Anderson, W. A. D. (1969) Possible mechanism of post-testicular antifertility action of 3-chloro-1,2-propanediol. Proc. Soc. exp. Biol. Med. 132, 656.

Jones, A. R., Davies, P., Edwards, K. \& Jackson, H. (1969) Antifertility effects and metabolism of $\alpha$ and epi-chlorohydrin in the rat. Nature, Lond. 224, 83.

Kirton, K. T., Ericsson, R. J., Ray, J. A. \& Forbes, A. D. (1970) Male antifertility compounds: efficacy of U-5,897 in primates (Macaca mulatta). 7. Reprod. Fert. 21, 275.

Mainland, D. \& Murray, I. M. (1952) Tables for use in fourfold contingency test. Science, N.Y. 116, 591 .

MARSH, R. E. \& HowARD, W. E. (1969) Evaluation of mestranol as a reproductive inhibitor of Norway rats in garbage dumps. $\mathcal{F}$. Wildl. Mgmt, 33, 133.

Samojlik, E. \& Chang, M. C. (1970) Antifertility activity of 3-chloro-1,2-propanediol (U-5,897) on male rats. Biol. Reprod. 2, 299.

SETTY, B. S. \& KAR, A. B. (1970) Nature and site of action of 3-chloro-1,2-propanediol-an oral antifertility agent for the male. Indian Jnl exp. Biol. 8, 49.

SetTy, B. S., Kar, A. B., Roy, S. K. \& Chowdhury, S. R. (1970) Studies with sub-toxic doses of alpha-chlorohydrin in the male monkey (Macaca mulatta). Contraception, 1, 279.

TURner, M. A. (1971) Effects of $\alpha$-chlorohydrin upon the fertility of spermatozoa of the cauda epididymidis of the rat. F. Reprod. Fert. 24, 267. 